NBER WORKING PAPER SERIES

EPILOGUE: FOREIGN-EXCHANGE-MARKET OPERATIONS IN THE TWENTY-FIRST CENTURY

\author{
Michael D. Bordo \\ Owen Humpage \\ Anna J. Schwartz \\ Working Paper 17984 \\ http://www.nber.org/papers/w17984
}

NATIONAL BUREAU OF ECONOMIC RESEARCH

1050 Massachusetts Avenue

Cambridge, MA 02138

April 2012

Michael Bordo is a Visiting Scholar at the Federal Reserve Bank of Cleveland and this paper is part of an ongoing research project there. The views expressed herein are those of the authors and do not necessarily reflect the views of the National Bureau of Economic Research, the Federal Reserve Bank of Cleveland, or the Board of Governors of the Federal Reserve System.

NBER working papers are circulated for discussion and comment purposes. They have not been peerreviewed or been subject to the review by the NBER Board of Directors that accompanies official NBER publications.

(C) 2012 by Michael D. Bordo, Owen Humpage, and Anna J. Schwartz. All rights reserved. Short sections of text, not to exceed two paragraphs, may be quoted without explicit permission provided that full credit, including (C) notice, is given to the source. 
Epilogue: Foreign-Exchange-Market Operations in the Twenty-First Century Michael D. Bordo, Owen Humpage, and Anna J. Schwartz

NBER Working Paper No. 17984

April 2012

JEL No. F31,F33,N2

\begin{abstract}
$\underline{\text { ABSTRACT }}$
Foreign-exchange operations did not end after the United States stopped its activist approach to intervention. Japan persisted in such operations, but avoided overt conflict with its monetary policy. With the on-set of the Great Recession, Switzerland has transacted in foreign exchange both for monetary and exchange-rate purposes, and key central banks have used swap facilities to extended their lender-of-last-resort functions. Developing and emerging market economies continue to intervene, but their actions may hamper the development of their own foreign-exchange markets. China's undervalued exchange rate is producing inflation and real appreciation, despite China's efforts to sterilize its reserve accumulation.
\end{abstract}

Michael D. Bordo

Department of Economics

Rutgers University

New Jersey Hall

75 Hamilton Street

New Brunswick, NJ 08901

and NBER

bordo@econ.rutgers.edu

Owen Humpage

Federal Reserve Bank of Cleveland

P.O. Box 6387

Cleveland, OH 44101-1387

owen.f.humpage@clev.frb.org
Anna J. Schwartz

NBER

365 Fifth Ave, 5th Floor

New York, NY 10016

aschwartz@gc.cuny.edu 


\section{Epilogue: Foreign-Exchange-Market Operations in the Twenty-First Century}

After the United States ended its activist approach to foreign-exchange-market intervention, many other advanced economies soon followed suit, but while such operations faded, they never disappeared. Among the large developed economies, Japan frequently intervened in the foreign-exchange market until early 2004, and the European Central Bank, with the Federal Reserve's participation, gave intervention a one-off whirl in 2001. The Great Recession seemed to pique interest in intervention again as exchange-rate volatility increased, and as threats of "currency wars" were heard. Switzerland undertook substantial foreignexchange operations both for monetary-policy and exchange-rate objectives. The Great Recession also saw the metamorphosis of official swap lines into a mechanism for channeling foreign-currency liquidity to strapped commercial banks. Among the developing and emerging market economies, particularly in China, foreign-exchange operations have remained a mainstay of macroeconomic policy and development strategy.

In this epilogue, we briefly describe five recent developments as they relate to the Federal Reserve's history with foreign-exchange operations. First, we argue that Japan's success with intervention has been broadly similar to the United States' experience. The United States is not unique. We also suggest that Japan's continued interest in such operations results because the interventions have not overtly conflicted with the aims of monetary policy in that country. Such a clash contributed to the end of intervention in the United States. Second, we describe Switzerland's recent experience with foreign-exchange-market operations. Switzerland offers a comparison of sterilized and non-sterilized interventions and a modern example of the fundamental trilemma of international finance. Switzerland cannot stabilize its exchange rate, maintain an independent monetary policy, and allow free cross-border financial flows. Third, we chart the renewed use of swap lines. They continue to signal central-bank cooperation, but whereas in the past, that collaboration focused on protecting the U.S. gold stock or on frustrating speculative sales of foreign currencies, it now aims primarily at extending a lender-of-last-resort function across national borders. The global integration of financial markets may demand such a function. We speculate that this new swap mechanism could remain a key instrument of centralbank operations going forward. Fourth, we briefly discuss intervention among the developing and emerging market economies. We, like others, argue that in their pursuit of exchange-rate stability, they run the danger of displacing those very market mechanisms that help traders and manufactures cope with market volatility. Fifth, we review China's exchange-rate policies. In recent years, China has sterilized part of its interventions, but should sterilized intervention work any better in China than in Switzerland or the United States? As a result of undervaluing the renminbi, China now faces inflation. All these issues provide fodder for further research.

\section{Japanese Intervention}

Unlike most other large developed economies, Japan has undertaken fairly frequent — and at times massive - intervention operations. Between April 1991 and March 2004, the main period of intense Japanese activity, the Ministry of Finance bought or sold U.S. dollars on 340 days, or approximately one out of every ten business days. Roughly 90 percent of the transactions were purchases of U.S. dollars, and the median dollar purchase (\$789 million) was more than three times as large as the median dollar sale (\$223 million). Over this time period, Japan generally moved aggressively to prevent sharp appreciations of the yen, especially when Japanese macroeconomic fundamentals were weak. An exchange rate below $¥ 125$ per dollar 
seemed to trigger the dollar purchases (Ito 2003, 2005, and Ito and Yabu 2007). As a result of these operations, which totaled nearly $\$ 615$ billion, Japan accumulated a huge portfolio of U.S. dollar-denominated reserves. ${ }^{1}$

American economists find Japanese intervention particularly interesting because of institutional similarities between the two countries. The Bank of Japan-like the Federal Reserve System - conducts its monetary policy independent of governmental fiscal authorities. The Japanese Ministry of Finance, however, has sole authority for intervention; the Bank of Japan only operates as its agent. Likewise, the U.S. Treasury has primary responsibility for U.S. intervention. While the Federal Reserve does maintain its own portfolio and has legal authority to act at its own discretion, it always operates in concert with the Treasury or with the approval of the Treasury. As with all official U.S. foreign-exchange transactions, Japanese interventions are routinely sterilized. In Japan, the Ministry of Finance issues fiscal bills to obtain the yen for intervention purchases of dollars. The yen is then re-injected into the banking system when the Bank of Japan conducts the transactions. The Ministry of Finance will place any yen acquired through dollar sales on account with commercial banks, thereby sterilizing the transactions. In any event, the Bank of Japan has the capacity to sterilize any intervention operation that conflicts with its monetary-policy objectives. The institutional similarities suggest that both countries seem to view sterilized intervention as a policy instrument capable of affecting exchange rates without sacrificing the domestic objectives of their monetary policies.

Using the same methodology as we adopt in this book (see appendix), Chaboud and Humpage (2005) tested the effectiveness of Japanese intervention and found results broadly similar to those for the United States. ${ }^{2}$ Over the entire $1991-2004$ period, when the Ministry of Finance was most active, Japanese purchases or sales of U.S. dollars demonstrated little correspondence with same-day yen depreciations or appreciations, but they were associated with more moderate movements of the yen-dollar exchange rate. This broadly similar finding suggests that the United States is not an entirely unique case, and that intervention has some modest effects.

In contrast to the consistency of the dollar's reaction to U.S. interventions between 1973 and 1995, the yen's response to Japanese operations between 1991 and 2004 changed substantially with the Ministry of Finance's operating strategies (see: Ito 2003, 2005, Chaboud and Humpage 2005, and Ito and Yabu 2007). During the first four years of the operations - as with the entire period-Japanese interventions were only associated with more moderate movements in the yen-dollar exchange rate. In sharp contrast to the first period, between 1995 and 2002, following the appointment of Eisuke Sakakibara as Director General of the Ministry of Finance's International Bureau, the typical size of a transaction increased ten-fold, but interventions occurred much less frequently and persistently. Then, purchases of dollars were associated with a same day depreciation of the yen that often represented a reversal in the yen's direction. Between late 2002 and early 2004, following the appointment of Hiroshi Watanabe as Director General, the typically size of an intervention fell by about one-half, but the frequency and persistence increased substantially. All of the transactions in this last period were unilateral purchases of dollars, and the Bank of Japan often concealed its presence in the market by placing standing orders with banks that entered the market under their own names. In this last period, interventions only seemed to moderate appreciations in the yen against the dollar.

Chaboud and Humpage (2005) also found that the probability of a successful Japanese transaction increased with its size. Acting in concert with the United States, however, had little, 
if any, effect on the probability that a Japanese intervention would be successful. (The United States participated in only 22 of the 340 Japanese interventions between 1991 and 2004.) Likewise, Bordo, et al. (2012) found that the probability of a successful U.S. intervention increased with its size. Coordinating a U.S. operation with another central bank-as in the Japanese case-had little impact on the likelihood of its success.

Since March 2004, the Bank of Japan has only intervened on four occasions. On 15 September 2010, the Bank bought $¥ 2.1$ trillion worth of dollars. On 18 March 2011, shortly after a devastating earthquake and tsunami, Japan intervened in concert with the United States and other G7 countries to slow a yen appreciation (Neely 2011). The Bank of Japan bought $¥ 0.7$ trillion equivalent dollars at that time. On 4 August 2011, the Bank of Japan bought $¥ 4.5$ trillion worth of dollars - then a record amount. On 31 October 2011, however, the Bank of Japan bought $¥ 9.1$ trillion worth of dollars - a new record amount. By summer 2011, the yen was trading at post-war highs relative to the dollar. Each of these operations has been associated with a short-lived depreciation of the yen. While the yen has not retreated from its post-war highs, it has, nevertheless, remained fairly stable since August 2011.

As documented in this book, FOMC participants frequently objected to sterilized interventions because the transactions often were at odds with U.S. monetary-policy goals and, therefore, weakened the System's credibility with respect to price stability. At a critical time in the late 1980s and early 1990s, the System bought foreign exchange when the FOMC was trying to tighten policy. In contrast, most Japanese interventions since 1991 have consisted of dollar purchases during a period of slow economic growth with very low inflation-even frequent bouts of deflation - and often with policy rates at the zero bound (see McCallum 2003). Under such circumstances, Japan's frequent dollar purchases seemed broadly consistent with the needed thrust of Japanese monetary policy and probably did not damage the Bank of Japan's credibility. Still, the potential for sterilized intervention to create uncertainty about monetary policy remains a key reason that central banks in major developed countries avoid its use. Japanese monetary authorities may someday encounter the same problem.

\section{Swiss Intervention}

Prior to the recent international financial crisis, the Swiss National Bank had not intervened in the foreign-exchange market since August 1995, but as world economic conditions deteriorated and as a sharply appreciating Swiss franc dulled Switzerland's competitive edge, the bank undertook foreign-exchange operations both to affect the value of the Swiss franc and to facilitate price stability, the bank's overarching policy objective. While the Swiss National Bank has a strong history of monetary and price targeting, the Bank has maintained a flexible approach. It temporarily deviated from a strict adherence to these targets in the late 1970s and in the mid-1990s when financial inflows produced severe exchange-rate movements. Adjusting policy to exchange-rate movements has precedent in Switzerland (Rich 1987, 2000).

The recent actions, however, provide a modern example of the difficulties inherent to such operations - a topic of this book. The latest sterilized Swiss interventions had no obvious lasting effect on the Swiss franc, and the resulting valuation losses brought political criticism on the operations. While the unsterilized interventions seemed to successful influence the Swiss franc, targeting an exchange rate exposed the country to claims of beggar-thy-neighbor behavior. Moreover, the operations raise questions about the benefit of conducting policy through foreign 
exchange instead of traditional instruments (repos or lending facilities), assuming of course that traditional instruments are sufficiently available.

In Switzerland - in contrast to the United States and Japan - the nation's central bank, the Swiss National Bank, has sole responsibility for foreign-exchange operations. Besides intervention, the Bank has recently used substantial amounts of foreign-exchange swaps to provide liquidity directly to non-Swiss European banks (see Auer and Kraenzlin 2011). These banks, which typically funded longer-term Swiss franc assets with very short-term liabilities, had difficulty financing their positions during the recent financial crisis.

On 12 March 2009, the Swiss National Bank eased monetary policy in response to expectations of deflation, deteriorating economic conditions, and financial-market tightness that resulted from the global financial crisis. At the time, despite declines in short-term interest rates, the Swiss National Bank viewed monetary conditions in Switzerland as highly restrictive because the Swiss franc had appreciated sharply on a trade-weighted basis and hovered around its all-time high (Swiss National Bank, 12 March 2009). The subsequent Swiss actions included a further policy-rate cut, quantitative easing measures, and foreign-exchange intervention. Immediately after announcing the policy changes, the Swiss National Bank aggressively bought euros in the foreign-exchange market, and the Swiss franc depreciated 5 percent against the euro over the next six days, from SF1.46 per euro to SF1.54 per euro.

Since the Swiss National Bank linked its interventions with a concern for deflationary pressures, observers have wondered what the actions represented. Were the unsterilized foreignexchange operations designed - first and foremost - to affect the exchange rate, or were they quantitative easing via foreign-asset purchases intended to encourage economic growth and prevent deflation? To be sure, these two alternatives are observationally and functionally equivalent; still, conducting quantitative easing through foreign-currency operations raises two issues: First, such actions may be necessary if Swiss-franc-denominated assets are unavailable, otherwise easing monetary policy through the purchase of foreign assets seems to have no bigger effect on exchange rates than such operations conducted through domestic assets. ${ }^{3}$ Second, in conducting policy through foreign exchange, the Swiss National Bank subjected itself to charges of beggar-thy-neighbor exchange-rate operations in the financial press.

Through March and April 2009, the Swiss National Bank did not seem to sterilize its substantial foreign-exchange purchases. The Swiss monetary base increased by more than the value of foreign assets on the Swiss National Bank's balance sheet, and in response to these policy actions, the Swiss franc depreciated and remained above SF1.50 per euro (see figure 1). By April 2009, the Swiss monetary base had more than doubled from a year earlier, and the Swiss National Bank - now concerned that the sharp rise in the monetary base might compromise medium to long-term price stability — began to sterilize the liquidity resulting from its huge interventions. ${ }^{4}$ The SNB's intervention purchases of euros continued through June 2010, but after April 2009, the Swiss monetary base either grew by less than the holdings of foreign assets at the Swiss National Bank or the monetary base actually declined. The Bank was clearly sterilizing its foreign-exchange operations. The Swiss franc appreciated 9.7 percent between April 2009 and June 2010. On balance between May 2010 and August 2011, the Swiss monetary base contracted as the Swiss National Bank attempted to offset the sharp earlier increase in the base. The franc's appreciation accelerated during the last half of 2010, and continued, by and large, through mid 2011. In August 2011, the Swiss franc reached an historic 
high on a real trade-weighted basis, implying a substantial loss of competitiveness since - at least - the beginning of the global financial crisis.

Following the heavy interventions, the subsequent depreciation of the euro resulted in substantial valuation losses to the Swiss National Bank. The Bank's profits are a revenue source both to the Swiss federal government and, especially, to the cantons. So, adding insult to injury, the Swiss National Bank endured political criticism for its ineffective foreign-exchange operations.

Figure 1: Change in the Swiss Monetary Base

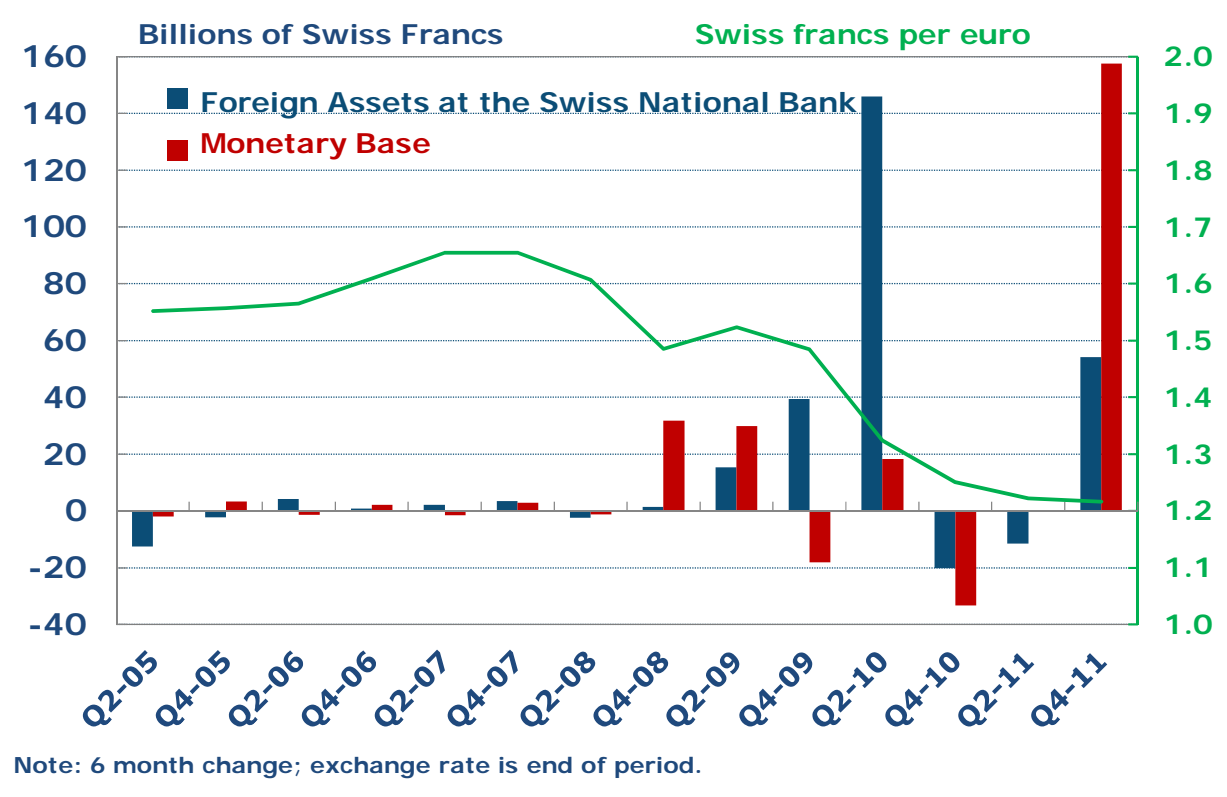

Source: Swiss National Bank/ Federal Reserve Board

Over three weeks beginning on 3 August 2011, the Swiss National Bank announced a series of new measures to inject liquidity into financial markets with the objective of stemming the Swiss franc's appreciation against the euro and dollar. The Bank viewed the Swiss franc as "massively overvalued" and a threat to price stability (Swiss National Bank, 3 August 2011). Among the measures, the Swiss National Bank would undertake foreign-exchange swaps in which it would sell Swiss francs spot and repurchase them forward. In addition the Bank would repurchase Swiss National Bank bills, which it often uses to sterilize interventions. The announcements did not indicate whether or not the Swiss National Bank intended to intervene directly in the foreign-exchange market, but, as reported below, the Bank's holdings of foreign exchange increased substantially in August 2011. As one might expect, the Swiss franc immediately began to depreciate against the euro.

After depreciating nearly 8 percent between 3 August and 29 August 2011, the franc undertook a stunning reversal. In response, on 6 September 2011, the Swiss National Bank announced that it would "no longer tolerate" the franc below SF1.20 per euro and that it was "prepared to buy foreign currency in unlimited quantities" to maintain this floor (Swiss National Bank, 6 September 2011). After expanding SF 27.2 billion in August, the Swiss National Bank's holdings of foreign currency assets jumped SF74.6 billion - a very substantial amount - in 
September. The Swiss monetary base increased by even more in both months, indicating that the monetary authorities had not sterilized the interventions. Since September, the Swiss National Bank has successfully maintained its exchange-rate floor against the euro. This implies that the Swiss National Bank will maintain a monetary policy broadly consistent with that of the European Central Bank.

\section{Swap Lines}

On 12 December 2007, the FOMC reestablished swap lines with key foreign central banks as a way of channeling emergency dollar funding to foreign depository institutions that otherwise lacked access to Federal Reserve borrowing facilities. ${ }^{5}$ Although targeted to foreign banks, the FOMC understood that these lending facilities could ease dollar funding pressures more broadly. Initially, the FOMC extended swap lines only to the European Central Bank and the Swiss National Bank, but the lines grew as the financial crisis unfolded, and by mid-2009, fourteen central banks, including some key emerging market central banks, had access to System swap facilities. As the subsequent narrowing of various risk spreads suggests, the swap lines successfully calmed market uncertainty (see Goldberg et al. 2010 and Fleming and Klagge 2010).

After 2000, financial-market innovation and sustained globalization spurred growth in banks' foreign-currency-denominated assets. ${ }^{6}$ European banks in particular greatly increased their holdings of dollar-denominated loans and securities. Banks funded these dollar positions largely in short-term, wholesale markets, either by borrowing dollars or - more often-by acquiring domestic currencies and converting them into dollars via foreign-exchange swaps. Although both funding routes created maturity mismatches, the latter seemed particularly risky. In 2007, according to the Bank for International Settlements, 78 percent of foreign-currency swap turnover reflected contracts with maturities of less than seven days (see McGuire and von Peter 2009, p. 54, fn \#10). The maturity mismatch left banks vulnerable to rollover problems.

As the global financial crisis spread in late 2007, heightened financial-market credit risk dried up dollar funding. Banks not only found it increasingly difficult to fund their exposures, but many acquired additional dollar assets as they backstopped structured investment vehicles (Fleming and Klagge 2010). Maturity mismatches lengthened and a severe dollar shortage emerged. Although U.S. branches of foreign banks that held reserves could borrow from the Federal Reserve, most foreign banks could not.

On 12 December 2007, the Board of Governors of the Federal Reserve System established the Term Auction Facility, which offered emergency dollar loans to U.S. depository institutions. At the same time, the Federal Open Market Committee established special liquidity swap lines with the European Central Bank and the Swiss National Bank. These swap lines essentially extended the Term Auction Facility's reach beyond U.S. borders by financing term dollar funding facilities for foreign banks.

As with previous swap lines, the parties to the new arrangements would conduct the spot and the forward legs of any transaction at the same exchange rate, thereby eliminating exchange risk. The European Central Bank and the Swiss National Bank drew on these swap lines at oneor three-month terms as they extended dollar liquidity to eligible commercial banks in their jurisdictions. The loans that the European Central Bank and the Swiss National Bank made to commercial banks were collateralized, and the interest rates on the dollar funds initially were equal to the lowest acceptable auction rate under the System's Term Auction Facility. The 
European Central Bank and the Swiss National Bank assumed all counter-party risk. The Federal Reserve did not invest the euros or Swiss francs that it acquired when its counterparts drew on the lines. Instead, the System held the foreign currencies in non-interest bearing deposits with the respective foreign central bank, and the foreign central banks paid the Federal Reserve the same interest that they earned on loans to their commercial banks. According to Fleming and Klagge (2010, p. 2 - 3): "This arrangement avoided reserve-management difficulties that might arise at foreign central banks if the Fed were to invest its foreign currency holdings in the market." Initially the swap lines with the European Central Bank and the Swiss National Bank amounted to \$20 million and \$4 million, respectively, but the amounts quickly expanded to $\$ 55$ million and $\$ 12$ million, respectively, just prior to the Lehman Brothers collapse on 15 September 2008.

Initially, too, the Federal Reserve sterilized the swap operations by selling Treasury securities from its portfolio. The System's balance sheet showed little increase during 2007 and in the first half of 2008, but after the Lehman Brothers collapse, the System's balance sheet expanded rapidly.

Dollar funding problems greatly intensified following the Lehman Brothers failure, and the Federal Open Market Committee accordingly expanded the special liquidity swap facilities in tandem with foreign central banks' dollar liquidity operations (see figure 2). By the end of September 2008, the System had offered swaps to nine central banks. The total facility had grown from $\$ 24$ million to $\$ 620$ million. By late-October 2008, the System eliminated the overall limit on the facilities for the Bank of England, the Bank of Japan, the European Central Bank, and the Swiss National Bank, and five more central banks - the Bank of Brazil, the Bank of Korea, the Bank of Mexico, the Bank of New Zealand, and the Monetary Authority of Singapore - obtained swap lines. Aizenman and Pasricha (2009) suggest that the Federal Reserve primarily extended swap lines to those emerging market economies in which U.S. banks had high exposures. At the program's peak in December 2008, swaps outstanding totaled more than $\$ 580$ billion and accounted for over 25 percent of the Federal Reserve System's total assets (Fleming and Klagge 2010, p. 5)

The swap lines allowed foreign central banks to channel dollar liquidity directly to domestic financial institutions, and the swaps expanded in size and maturity structure along with the lending facilities of the foreign central banks. The programs that the foreign central banks offered varied in terms of eligibility, collateral requirements, and auction types. On 13 October 2008, in the wake of the Lehman Brothers' collapse, the Bank of England, the Bank of Japan, the European Central Bank, and the Swiss National Bank began offering "full allotments" of dollar liquidity - that is, as much as local commercial banks desired — at a fixed interest rate equal to 100 basis points over the OIS rate. ${ }^{8}$ To accommodate their full allotment format, the Federal Open Market Committee removed the limits on swap drawing by these four central banks. As market turmoil calmed in 2009, and as market rates no longer exceed the OIS rate by more than 100 basis points, central-bank lending facilities were no longer advantageous to financial institutions. Swap drawings fell off in turn.

Use of the swap lines peaked in December 2008 (see figure 2). The European Central Bank, whose outstanding drawings reached $\$ 300$ billion in late 2008 , was the biggest single user of the facility, followed by the Bank of Japan, and the Bank of England. Although swap borrowing fell off in 2009, funding markets continued to differentiate between strong and weak financial institutions (Goldberg, et al. 2010, p. 19 - 20). After a couple of extensions, the initial 
swap lines expired on 1 February 2010. Brazil, Canada, New Zealand, and Singapore never drew on their swap lines. By most accounts the swaps were successful in channeling dollar liquidity and calming markets (Goldberg, et al. 2010).

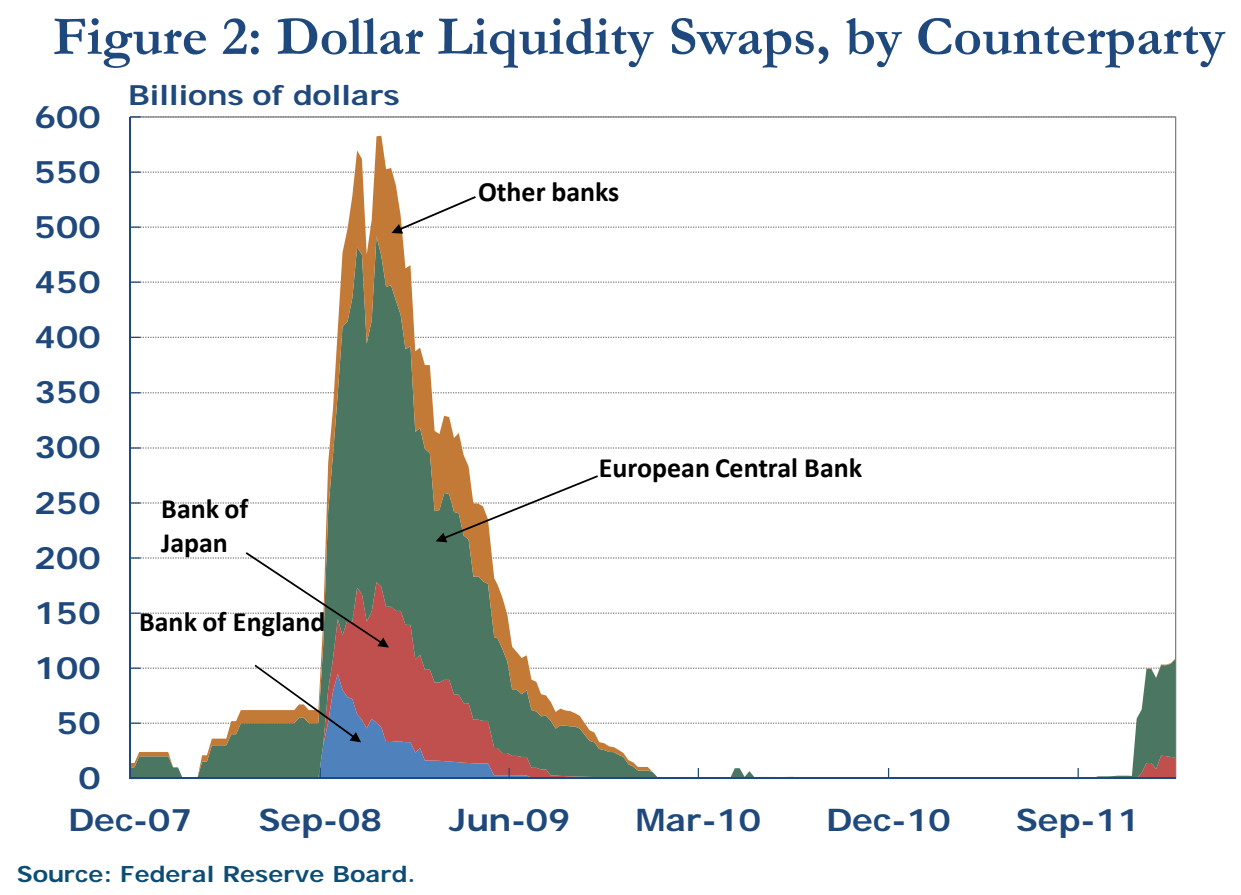

Unlike most previous swap agreements, the post-2007 lines were not reciprocal. The System did not use (or invest) the foreign exchange that it acquired through the swaps. In April 2009, the System established parallel swap lines with the Bank of Canada, the Bank of England, the Bank of Japan, the European Central Bank, and the Swiss National Bank that allowed the System to draw foreign currencies against dollars. These lines could channel emergency funding through the System to U.S. banks experiencing liquidity problems in foreign currencies. The System never drew on these lines.

The 1 February 2010 swap-line hiatus was short-lived. On 9 May 2010, as the European debt problem roiled still-fragile financial markets, the Federal Reserve re-established swap lines with the Bank of Canada, the Bank of England, the Bank of Japan, the European Central Bank and the Swiss National Bank at a rate of 100 basis points over the OIS rate. With the exception of the swap line with the Bank of Canada, which maintains an overall limit of $\$ 30$ billion, the other facilities are again open-ended to allow foreign central banks to auction dollar liquidity in a fixed-rate full-allotment format. On 30 November 2011, to make the facilities more attractive to commercial banks, the participating central banks lowered the interest rate on these lines to 50 basis points over the OIS rate. In addition, on 30 November 2011, the Bank of Canada, the Bank of England, the Bank of Japan, the European Central Bank, and the Swiss National Bank agreed to make temporary swap lines available to each other so that emergency liquidity is available in each of the currencies to each of the participants. All of these lines currently are scheduled to expire on 1 February 2013. 
There was some controversy over extending swap lines to countries that held substantial amounts of reserves - presumably dollar reserves. William Poole, the President of the Federal Reserve Bank of St. Louis, voted against establishing swap lines with the European Central Bank and the Swiss National Bank. He viewed the lines as unnecessary given the size of the dollardenominated reserves held by these institutions (Minutes 11 December 2007, pp. 1,9). In the end, however, most of the countries that received swap lines (in dollars or in other currencies) did not seem to hold sufficient reserves to meet the liquidity demands of the financial crisis (Moessner and Allen 2010; Obstfeld, et al. 2009). Swaps can augment reserves and-what is often equally important - signaled central-bank cooperation.

Besides these Federal Reserve swap lines, other central banks — notably the Bank of Japan, the European Central Bank, the Swiss National Bank, and the Peoples Bank of China have established swap arrangements with many emerging market economies (see Moessner and Allen 2010 and Aizenman, et al. 2010). The ECB made euro swaps available to many European countries outside of the European Monetary Union to stem liquidity shortages, although not all countries experiencing euro liquidity problems received swap lines. Likewise, the Swiss National Bank made Swiss franc swaps available to countries experiencing Swiss franc liquidity shortages. The Bank of Japan extended a yen swap line to South Korea and the Japanese Ministry of Finance extended a dollar swap line to India (Moessner and Allen 2010, p. 32 - 33).

East Asia has had an extensive swap network in place since 2000, as a means of offering financial support should a financial crisis like the one experienced in 1997 and 1998 reemerge. These swaps are designed to foster closer economic integration in the area (Moessner and Allen 2010, p 32). The Peoples Bank of China extended new swap lines during 2008 and 2009 both to provide a backstop against financial stress, but largely to promote the use of non-dollar currencies in regional trade and investment (Moessner and Allen 2010, p. 33). Besides Asian countries, the Peoples Bank extended swap lines to the National Bank of Belarus and the Central Bank of Argentina.

Even though many of these swap arrangements are scheduled to expire at their maturity. The precedent of using swaps for the emergency provision of liquidity denominated in key currencies now seems fairly well established. The dollar lines clearly enhance the currency's role as the key international reserve currency and may be necessary if that role is to continue. These swap arrangement are likely to persist.

\section{Foreign-Exchange Operations in Developing and Emerging Market Economies}

Unlike the major developed countries, which generally stopped intervening after the mid1990 s, the developing and emerging market economies continue frequent operations in their foreign-exchange markets. These small, open economies show a striking aversion to exchangerate volatility (Calvo and Reinhart 2000). Exchange-rate volatility can often have serious macroeconomic consequences in these economies because they frequently lack hedging facilities that protect domestic firms from that volatility. Ironically, the frequent interventions that developing and emerging market countries undertake, together with other policies that they pursue to increase the effectiveness of those interventions, can limit the very financial development that they so badly need.

Assessing the intervention activities in developing and emerging market economies is not straightforward. Their financial markets are underdeveloped and often tightly regulated. They often impose restrictions on cross-border financial flows. Their interventions are not always 
sterilized, and, hence, they are a product of monetary policy as much as exchange-rate policy. Their motives for buying or selling foreign exchange vary widely-beyond what we have heretofore considered intervention. Still, because of their unique characteristics, these countries provide useful laboratories for understanding the behavior of exchange rates and the effectiveness of intervention. ${ }^{9}$

In many developing and emerging market economies, the foreign-exchange market is aif not the - key asset market, and the local central bank is often the dominant player in that market. Almost by definition, foreign-exchange markets in these developing and emerging market countries are underdeveloped, particularly at the interbank level (Canales-Kriljenko 2004). They lack liquidity and a broad array of financial products, particularly hedging facilities. Besides attempting to stabilize exchange rates, central banks in these countries often act as fiscal agent for the government, buying and selling foreign exchange to finance cross-border expenditures, to service foreign-currency-denominated debts, or to adjust foreign-exchange reserves. In countries where the government is a key source of foreign-exchange earnings - for example, oil producing nations - central banks may play an important role in channeling foreignexchange receipts to the market. Because of their familiarity with the market, central banks may also act as their governments' administrators of the foreign-exchange market. In that role, they often cast a broad web of regulations upon market participants, deciding who might trade foreign exchange, specifying the markets in which they operate, and limiting their positions and exposures. Central banks may also enforce macroeconomic controls on cross-border financial flows.

In a survey of foreign-exchange activity in developing and emerging market economies Canales-Kriljenko $(2003,2004)$ found that most central banks in these countries participate in the market irrespective of the underlying exchange-rate regime. They often intervene heavily in markets characterized as flexible or floating. Surprisingly, however, less foreign-exchange intervention occurs under credible fixed exchange-rate regimes. If an exchange-rate peg is credible, foreign-exchange intermediaries tend to act as stabilizing speculators, minimizing the need for official intervention (Canales-Kriljenko, 2003, pp. 6-7).

The key objective of frequent intervention in developing and emerging-market economies is to limit exchange-rate volatility. As noted, foreign-exchange markets in these countries tend to be thin, concentrated among a few traders, and generally underdeveloped, which can magnify the response of foreign-exchange rates to economic shocks or new information. Because developing and emerging market economies are often not well diversified, lack credibility with respect to their macroeconomic-policy objectives, and rely heavily on traded goods and foreign financing, exchange-rate volatility can quickly translate into macroeconomic instability. The lack of hedging facilities in particular is an important structural problem fast linking exchangerate volatility to macroeconomic instability.

While exchange-rate stability is the key reason for intervention in developing and emerging market economies, acquiring foreign-exchange reserves and providing foreign exchange to market participants are often important objectives of a central bank's market operations. Developing and emerging market countries often buy foreign exchange to accumulate foreign-currency reserves. Many countries see holding substantial portfolios of foreign-exchange reserves as a means of building investor confidence by strengthening their debt-repayment capabilities, and maintaining external liquidity (Canales-Kriljenko, et al. 2003). ${ }^{10}$ Moreover, buying and selling foreign exchange is necessary if the central bank is the 
key intermediary for foreign exchange in countries where the government is the chief foreign currency recipient.

When operating in the foreign-exchange market, only about one in five developing or emerging market economies routinely sterilizes their interventions (Canales-Kriljenko, 2003, p.8). Some countries simply undertake monetary policy using an exchange-rate target and dealing in foreign exchange; persistent sterilization would be antithetical to such an operation. For many others, sterilization is difficult or socially costly. They may lack financial instruments with which to quickly sterilize an operation, or the instruments may be of short duration and, therefore, require frequent rolling over or management (Morano 2005, p. 16, and Mohanty and Turner 2005). Heavy persistent sterilized purchases of foreign exchange may eventually raise questions about the monetary authority's ability to service their outstanding government or central-bank securities. Likewise, frequent sterilized intervention in thin or otherwise underdeveloped money markets may also distort relative prices among asset categories. The interest cost of sterilization bonds to the monetary authority can easily exceed the interest returns on their liquid foreign-currency asset, while the return on the sterilization bonds to commercial banks can fall far short of their opportunity cost (Lardy 2008). All this fosters inefficiencies through sterilization.

Still, according to Canales-Kriljenko (2003), the interventions that emerging market economies undertake in their less-developed local markets - even when completely sterilizedare very often more effective than the interventions that advanced countries undertake in their fully developed markets. This can even be the case if the central bank in question lacks credibility with respect its domestic-policy objectives.

Central banks in developing and emerging market economies frequently have the advantage of being big fish in little ponds. They often intervene in amounts that are large relative to the size of local foreign-exchange-market turnover, their own monetary bases, and the stock of their outstanding government bonds. Hence it is very likely that either a portfoliobalance mechanism, or an order flow channel, or an expectations effect is open to them. Sometimes central banks in developing and emerging market economies achieve their relative size advantage through their regulatory powers and their use of exchange controls. Such regulations as surrender requirements, prohibitions of interbank trading, or restrictions on taking net-open positions, effectively increase the size of intervention relative to market turnover because they either reduce the size of the foreign-exchange market or concentrate foreign exchange at the central bank, or both. Foreign exchange controls in many countries require their residents to use the domestic currency — instead of a foreign currency — when making payments to other residents, and often limit their ability to hold foreign-currency deposits in banks. Some also impose controls on the use of their domestic currency by nonresidents. These all decrease the effective size of the foreign-exchange market, increasing the impact of intervention.

The key role of central banks as foreign-currency intermediaries in some local foreignexchange markets, the important role of central banks as regulators in many local foreignexchange markets, and the lack of an extensive interbank segment in these markets is also very likely to confer an informational advantage on the central bank. If so, a central bank might be able to successfully exploit an expectation channel through its intervention. A strict policy signaling channel, however, would be impaired if the central bank lacked policy credibility or if ongoing structural change in the economy loosened the connection between financial and real variables (Canales-Kriljenko et al. 2003) 
In contrast, the portfolio-balance channel does not depend on the credibility of the monetary authorities. Galati et al. (2002) originally speculated that the portfolio-balance effect could potentially operate in emerging market economies, even though empirical evidence generally offers little support for a portfolio-balance channel among advanced economies. As previously mentioned, emerging market countries are likely to hold larger portfolios of foreignexchange reserves relative both to the local exchange market and to the stock of outstanding local-currency bonds than their wealthier counterparts. These are sufficient conditions, but the key necessary condition is also likely to hold: The degree of substitution between bonds denominated in their own currencies and bonds denominated in reserve currencies is very likely to be small. Hence, the risk premium is likely to be larger and more sensitive to changes in the relative stocks of assets.

A temporary order-flow mechanism may also operate better in a developing or emerging market economy than in an advanced market because of the relative size and importance of central banks in underdeveloped markets. In addition, as explained above, central banks in emerging market economies may have better information about order flow than other market participants.

Unlike their advanced-country counterparts, central banks in emerging market economies often use "oral interventions" to affect exchange rates. Because emerging market central banks often regulate their exchange markets more heavily than developed countries - e.g., grant licenses, authorize individual dealers, regulate the market - they derive considerable leverage from their regulatory authority. Ideally, verbal intimidation might complement an expectations mechanism, but excessive use could clearly hamper market development (Canales-Kriljenko 2003, p. 24).

In the limit, as the literature clearly suggests, the relative success that developing and emerging market economies may have in conducting effective foreign-exchange-market operations can intensify the very problem that they seek to avoid. In their desire to foster stability through intervention, regulation, and control, monetary authorities in these countries often discourage private-sector financial innovation and maintain the market's backwardness. When such operations hamper financial-market development, they can actually intensify the macroeconomic consequences of exchange-rate volatility.

\section{China's Renminbi-Dollar Peg}

No country's exchange-rate practices have incited as much controversy as China's have generated. U.S. policymakers in particular have accused China of artificially undervaluing the renminbi relative to the dollar in order to achieve a trade advantage. China's massive accumulation of foreign-exchange reserves is, indeed, testament to such charges, but whatever trade advantage China obtains from undervaluing the renminbi should be transitory. China's control over its nominal exchange rate does not extend to its real exchange rate. Price level pressures, emanating primarily from its exchange-rate practices, must eventually induce a real renminbi appreciation and erode any competitive edge that the undervaluation provides. This process has been occurring. Although the Peoples Bank of China has sterilized a substantial part of the reserve accumulation since 2002, this has not prevented inflation and a real appreciation. The renminbi has appreciated 25 percent against the dollar in real terms and 34 percent on a real trade-weighted basis since $1995 .^{11}$ 
Over the past seventeen years, China's exchange-rate regime has shifted back and forth between a peg against the U.S. dollar and a tightly controlled appreciation. In July 2005, after pegging the renminbi at $¥ 8.3$ per dollar over the previous decade, China undertook a controlled appreciation of its currency against the U.S. dollar. ${ }^{12}$ The Peoples Bank of China interrupted the appreciation briefly with a renewed peg between July 2008 and June 2010 in response to adverse spillovers from the global financial crisis. Since then, the renminbi has again undergone a controlled appreciation against the dollar, bringing the total nominal appreciation since mid-1995 to 28 percent against the dollar.

In addition to systematically undervaluing its currency, China also discourages private financial outflows, largely by limiting the amount of foreign currencies that China's residents might hold and their ability to invest those currencies abroad in foreign assets. These controls, in conjunction with China's exchange-rate policies, have resulted in a massive accumulation of foreign exchange reserves, even during the years of renminbi appreciation. Between mid 1995 and December 2011, China's official foreign-exchange reserves rose from $\$ 250$ billion (equivalent) to $\$ 3.2$ trillion. Most of this foreign-exchange-reserve accumulation, however, took place after 2001 with important monetary consequences (see figure 3).

\section{Figure 3: China's Official Reserves}

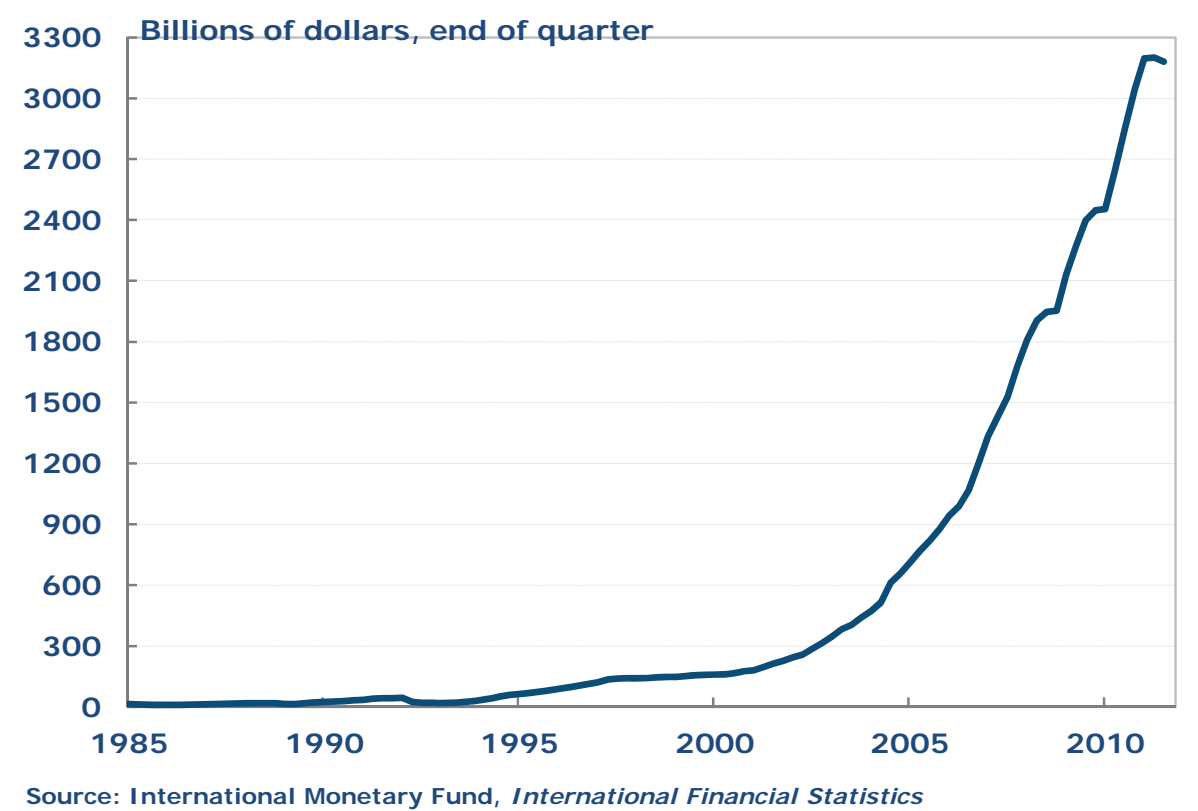

Prior to 2003, the Chinese monetary base increased modestly relative to the country's rapid growth rate. The disparity was such that China often experienced deflation between 1997 and 2003, and the renminbi depreciated against the dollar on a real basis despite the nominal peg (see figure 4). In 2003, however, the situation changed. Reserve accumulation picked up, as did China's monetary base and its inflation rate. Since then, China's accumulation of foreignexchange reserves has been especially heavy. To limit the inflation consequences of its exchange-rate policies, the Peoples Bank started selling sterilization bonds to local commercial banks. ${ }^{13}$ From the end of 2003 through 2009, the Peoples Bank offset 41 percent of its reserve accumulation, but the monetary base continued to grow sharply (see figure 5). In addition, the 
Peoples Bank increased reserve requirements on banks 19 times, from 6 percent to 17.5 percent. $^{14}$

Figure 4: Renminbi-Dollar Exchange Rate

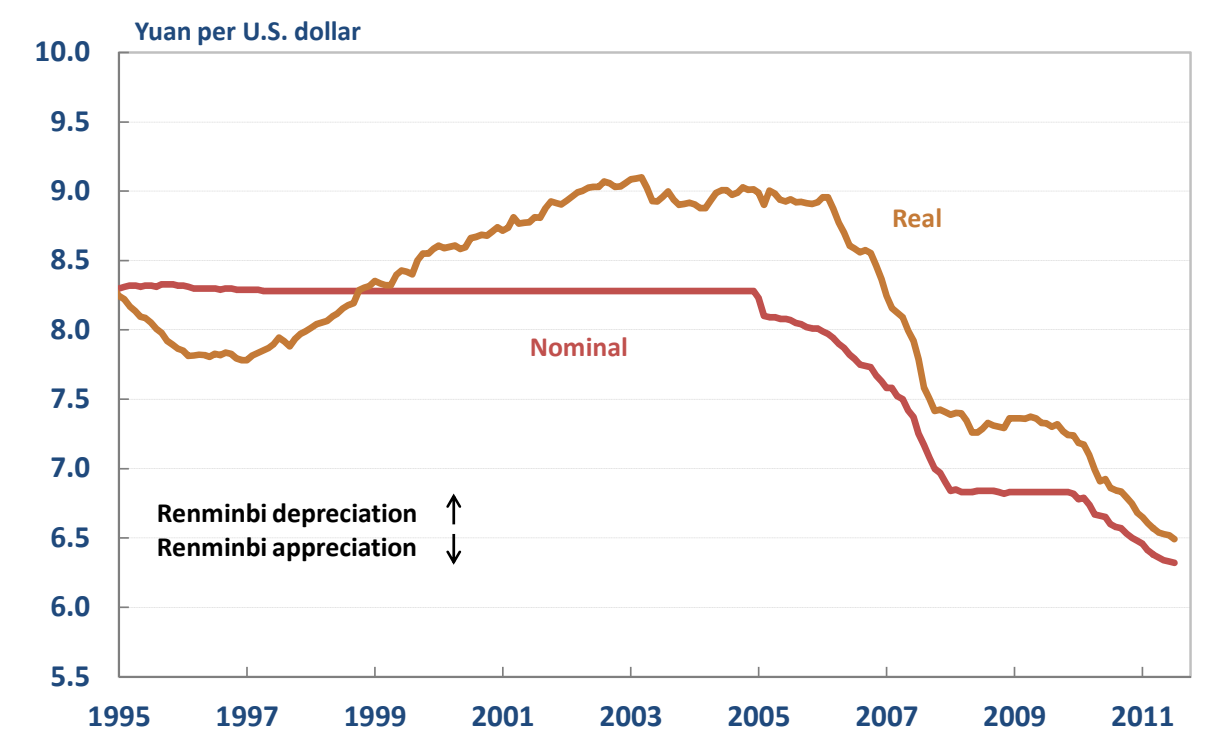

Source: Bureau of Labor Statistics, China National Bureau of Statistics/Haver Analytics, International Monetary Fund

\section{Figure 5: Sterilization of Reserve Flow in China}

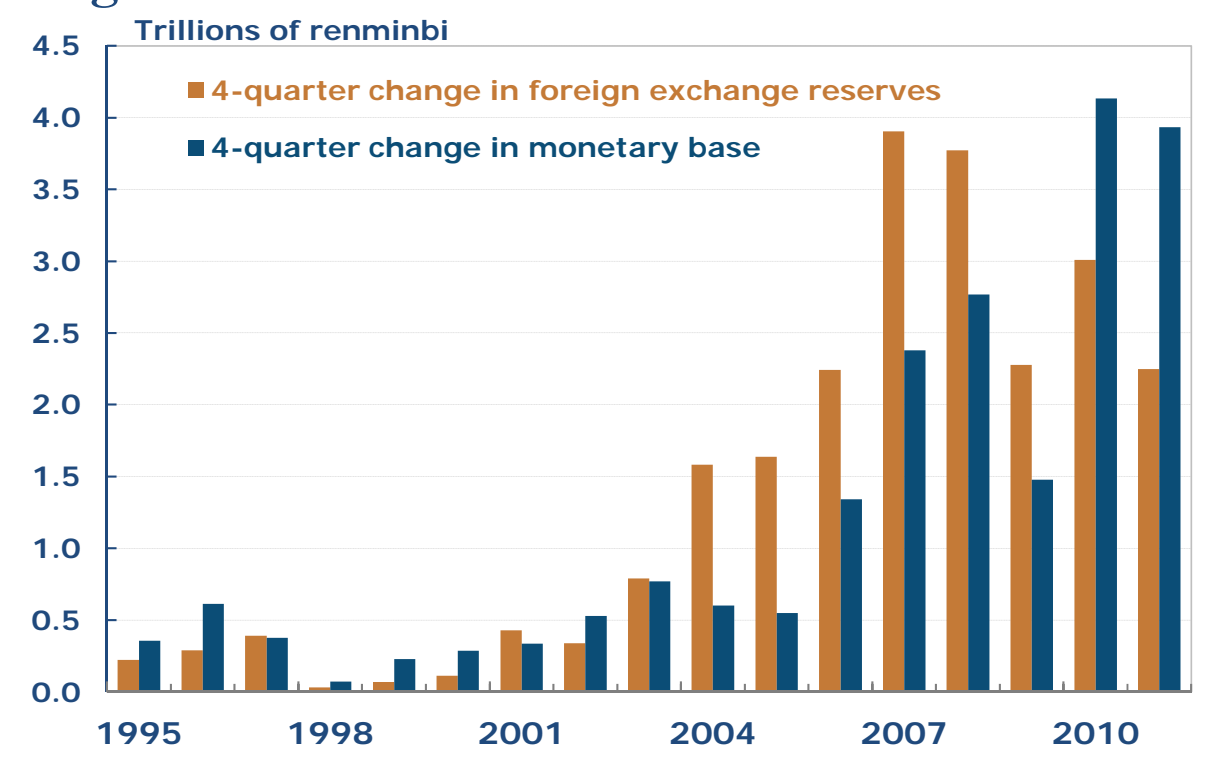

Source: I nternational Monetary Fund, I nternational Financial Statistics

This operation is puzzling. China's sterilized intervention could only maintain the peg or limit nominal appreciation if a portfolio-balance mechanism were at work, and, as we have shown, the empirical support for such a mechanism - at least among advanced economiesseems nonexistent. Because China undervalues the renminbi, it experiences an excess demand 
for its currency. In defense of the peg or to limit appreciation, the Peoples Bank of China must buy foreign exchange and must issue sufficient renminbi base money to meet that excess demand. Effectively, this requires non-sterilized intervention-an expansion of the money supply - to prevent a renminbi appreciation. When China subsequently sterilizes the resulting monetary-base growth, the excess demand for renminbi cannot be met through a supply of renminbi. To maintain the peg or limit appreciation, the issuance of sterilization bonds must raise the nominal interest rate sufficiently - via an increased risk premium - to reduce the demand for renminbi. Has this happened? Demonstrating that the Peoples Bank of China sterilizes part of the reserve accumulation is necessary, but not sufficient, for explaining the renminbi's peg or its limited nominal appreciation.

Although the Peoples Bank of China did seem to offset part of the monetary impact from its reserve accumulation between 2004 and 2009, the monetary base, nevertheless, generally grew faster after 2003 than it did before that date. In 2010 and 2011, the monetary base outpaced reserve growth by nearly two to one. Although the Peoples Bank of China increased reserve requirements from 15.5 percent to 21.5 percent over the past two years, China has experienced a sharp run up in its inflation rate, and a continued real renminbi appreciation.

China may undervalue its nominal exchange rate, but it has not controlled its real exchange rate, and the latter-not the former-ultimately determines equilibrium. In late 2011, on the heels of a 25 percent cumulative real renminbi appreciation against the dollar, China's foreign-exchange reserves began to fall (figure 3). While it is still too early to tell, the real appreciation may have restored nominal equilibrium, and China's experience may illustrate adjustment under a peg when sterilized intervention and financial restraints ultimately prove ineffective. 


\section{References}

Auer, Raphael and Kraenzlin, Sébastian. 2011. "International Liquidity Provision during the Financial Crisis: A View from Switzerland," Federal Reserve Bank of St. Louis, Review 93(6): $409-417$.

Aizenman, J., Jinjarak, Y. and Park, D. 2010. “International Reserves and Swap Lines: Sustitutes or Compliments?" National Bureau of Economic Research Working Paper 15804 (March)

Aizenman, Joshua and Pasricha, Gurnain Kuar. 2009. "Selective Swap Arrangements and the Global Financial Crisis: Analysis and Interpretation," National Bureau of Economic Research Working Paper 14821 (March).

Bank for International Settlements. 2005. "Foreign Exchange Market Intervention in Emerging Markets: Motives, Techniques, and Implications." Bank for International Settlements Papers No. 24 (May).

Bonser-Neal, C., Roley, V. V. and Sellon, G. H. Jr. 1998. Monetary Policy Actions, Intervention, and Exchange Rates: A Reexamination of the Empirical Relationships Using Federal Funds Rate Target Data. Journal of Business, 71(2): 147-177.

Bordo, M. D., Humpage O.F. and Schwarz A.J. 2012. “The Federal Reserve as an Informed Foreign Exchange Trader: 1973 - 1995," International Journal and Central Banking 8(1): $1-29$.

Calvo, G.A. and Reinhart, C. M. 2000. "Fear of Floating," National Bureau of Economic Research Working Paper 7993 (November).

Canales-Kriljenko, Jorge Iván. 2003. "Foreign Exchange Intervention in Developing and Transition Economies: Results of a Survey," International Monetary Fund Working Paper $\mathrm{WP} / 03 / 99$

Canales-Kriljenko, Jorge Iván. 2004. "Foreign Exchange Market Organization in Selected Developing and Transition Economies: Evidence from a Survey," International Monetary Fund Working Paper WP/04/4

Canales-Kriljenko, Jorge Iván, Guimariães, and Karacadağ, Cem. 2003. “Official Intervention in the Foreign Exchange Market: Elements of Best Practice," International Monetary Fund Working Paper WP/03/152

Chaboud, A. P., and Humpage, O. F. 2005. "An Assessment of the Impact of Japanese ForeignExchange Intervention: 1991 - 2004.” Board of Governors of the Federal Reserve System, International Finance Discussion Papers No. 824.

Fatum, R. and Hutchinson, M. 2003. Effectiveness of Official Daily Foreign Exchange Market Intervention Operations in Japan. National Bureau of Economic Research Working Papers No. 9648. 
Fleming, M. J. and Klagge, N. J. 2010. The Federal Reserve's Foreign Exchange Swap Lines, Federal Reserve Bank of New York Current Issues in Economics and Finance. 16(4) April.

Frenkel, M., Pierdzioch, M. and Stadtmann, G. 2005. "The Effects of Japanese Foreign Exchange Market Interventions on the Yen/US Dollar Exchange Rate Volatility," International Review of Economics and Finance 14(1):27 - 39.

Galati, G. Melick, W. and Micu, M. 2005. Foreign Exchange Market Intervention and Expectations: The Dollar/Yen Exchange rate. Journal of International Money and Finance. 24(6): $982-1011$.

Goldberg, L. S., Kennedy, C., and Miu, J. 2010. "Central Bank Dollar Swap Lines and Overseas Dollar Funding Costs," Federal Reserve Bank of New York Staff Report, No. 429 (February).

Humpage, O. F. 1999. U.S. Intervention: Assessing the Probability of Success. Journal of Money Credit and Banking 31 (4):731 - 747.

Humpage, O. and Ragnartz, J. 2005. Swedish Intervention and the Krona Float, 1993 - 2002. Federal Reserve Bank of Cleveland Working Paper 05-14.

Ito, T. 2003. "Is Foreign Exchange Intervention Effective?: The Japanese Experiences in the 1990s." in Paul Mizen (ed.) Monetary History, Exchange Rates, and Financial Markets, Essays in Honour of Charles Goodhart, (2) Cheltenhan, U.K.: Edward Elgar.

Ito, T. 2005. "Interventions and Japanese Economic Recovery." International Economics and Economic Policy 2(2-3): 219-239.

Ito, T. and Yabu, T. 2007. "What Prompts Japan to Intervene in the Forex Market? A New Approach to a Reaction Function," Journal of International Money and Finance 26(2): $193-212$.

Kos, D. 2001. "Treasury and Federal Reserve Foreign Exchange Operations," Federal Reserve Bulletin, Board of Governors of the Federal Reserve System: Washington, D. C. 87(12): 757 - 762 .

Lardy, N. 2008. "Financial Repression in China," Peterson Institution Policy Brief, No. PB08-8

Moessner, R. and Allen, W. A. 2010. "Central Bank Co-operation and International Liquidity in The Financial Crisis of 2008-9," Bank for International Settlements Working Papers No. 310, (May).

McCallum, B. T. 2003. "Japanese Monetary Policy, 1991-2001.” Federal Reserve Bank of Richmond Economic Quarterly 89 (1): 1-31.

McGuire, P. and von Peter, G. 2009. "The US Dollar Shortage in Global Banking," Bank for International Settlements Quarterly Review (March) 47 - 63.

Minutes of the Federal Open Market Committee, Board of Governors of the Federal Reserve System: Washington, D. C. 11 December 2007.

Mohanty, M. S. and Turner, P. 2005. "Intervention: What Are The Domestic Consequences?" Bank for International Settlements Papers \#24 (May) 56 - 81. 
Morano, R. 2005. “Motives for Intervention,” Bank for International Settlements Papers \#24 (May) $56-81$.

Neely, C. J. 2011. Foreign Exchange Intervention in an Era of Restraint," Federal Reserve Bank of St. Louis, Review 93(6): $302-324$.

Obstfeld, M., Shambaugh, J. C. and Taylor, A. M. 2009. "Financial Instability, Reserves, and Central Bank Swap Lines in the Panic of 2008," National Bureau of Economic Research Working Paper 14826. (March).

Ouyang, A.Y., Rajan, R.S. and Willete, T.D. 2010. "China as a Reserve Sink: The Evidence from Offset and Sterilization Coefficients," Journal of International Money and Finance. 29: $951-972$.

Rich, G. 2000. "Monetary Policy without Central Bank Money: A Swiss Perspective," International Finance. 3(3): 439 - 469.

Swiss National Bank. 2009. Quarterly Assessment. 12 March

Swiss National Bank. 2010. Quarterly Bulletin. June. 28(2)

Swiss National Bank. 2011. Communications ( 3 August).

Swiss National Bank. 2011. Communications ( 6 September). 


\section{ENDNOTES}

${ }^{1}$ Dollar amounts of Japanese intervention are from Chaboud and Humpage (2005)

2 Studies of Japanese intervention include Fatum and Hutchinson (2003), Frenkel, Pierdzioch, and Stadtmann (2005), Galati, Melick, and Micu (2005). Humpage and Ragnartz (2005) apply the same methodology as Chaboud and Humpage (2005) to Swedish intervention.

${ }^{3}$ There is not much empirical evidence on this equivalence issues. Our conclusion stems primarily from Bonser-Neal, et al. (1998), which investigated U.S. monetary policy and Humpage (1999), which looked at U.S. intervention policy.

${ }^{4}$ On the concern for the longer-term outlook for inflation see Swiss National Bank (2010. p. 42).

${ }^{5}$ Following the 11 September 2001 terrorist attacks, the System also instituted similar swap lines with the European Central Bank ( $\$ 50$ billion) and the Bank of England ( $\$ 30$ billion). At that time, the System expanded its existing swap with the Bank of Canada to $\$ 10$ billion. The lines expired after 30 days. The European Central Bank drew $\$ 23.4$ billion on its line and repaid the amount on 17 September 2001. The Bank of Canada and the Bank of England did not draw on the lines. See Kos (2001, p. 761).

${ }^{6}$ Our discussion of foreign banks' balance sheets draws on: McQuire and von Peter (2009), and Moessner and Allen (2010). See also Fleming and Klagge (2010) and Goldberg, et al. (2010).

${ }^{7}$ On this aspect of the swap lines, see especially Goldberg, et al. (2010).

${ }^{8}$ An Overnight Index Swap (OIS) is an interest-rate swap where the period floating rate in the swap is equal to a geometric average of the federal funds rate. The OIS rate refers to the floating rate portion of the swap. Hence the OIS rate is related to the average federal funds rate over the period of the obligation.

${ }^{9}$ A very good introduction to exchange-market operations in developing and emerging market economies is: Canales-Kriljenko (2003, 2004) and Canales-Kriljenko et al. (2003). This section drew heavily on these articles. See also the papers in Bank for International Settlements (2005). These sources also provide many useful references.

${ }^{10}$ As noted in chapter 4, the United States bought foreign exchange to build a portfolio of foreign-exchange reserves in the late 1970s and early 1980s.

${ }^{11}$ We calculated the trade-weighted appreciation using J.P. Morgan's real, broad, effective exchange-rate index.

${ }^{12}$ China's currency is the renminbi, but its currency unit is the yuan, whose symbol is $¥$.

13 The Peoples Bank also raised reserve requirements and imposed direct controls on bank lending to control inflation.

14 On sterilization, see also Ouyan, et al. (2010) and references therein. 